\title{
Actors (Media policy/ Meta journalism)
}

\section{AUTHOR}

Stefano Pedrazzi

\section{KEYWORDS}

self-coverage, media policy, intermediaries, opportune testimonies, news bias

\section{BRIEF DESCRIPTION}

The variable "actors" records individuals or collectives, who appear as a source for assertions of facts and evaluations and whose actions, interests or demands are addressed in an article (Hillebrand, 2005). In the case of media self-coverage, and especially when dealing with media policy issues, media organizations themselves might be affected by them. Hence, media organizations may strategically use their privileged access to the public to promote their own interests, for example by selecting actors and positions that will be publicly heard. Several studies have found a predominance of "opportune actors" and experts representing a position that supports media organization's own interests (Kemner, Scherer, \& Weinacht, 2008; Lichtenstein, 2011; Maier \& Dogruel, 2016).

FIELD OF APPLICATION/THEORETICAL FOUNDATION The variable serves to identify the actors involved in specific media discourses and can serve as an indicator for attempted influence by media organizations through biased selection.

\section{EXAMPLE STUDIES}

Hillebrand, 2005; Pedrazzi, 2020

INFORMATION ON PEDRAZZI, 2020

Research interest: Pedrazzi (2020) investigates Swiss media coverage of media policy, public service in general and the Swiss public service organization SRG SSR in the context of the referendum on the revision of the Federal Act on Radio and Television (RTVA) in 2015 and the NoBillag initiative in 2018.

Object of analysis: Representative samples of articles covering each the revision of the RTVA and the No-Billag initiative in twelve regional and national Swiss German print and online publications with different ownership.

Time frame of analysis: January 1, 2010 to March 4, 2018

\section{INFORMATION ABOUT VARIABLE}

Level of analysis: article

Operationalization/Coding instructions:

"The main actor and the two most important secondary actors mentioned in the article and who speak directly or indirectly on media policy issues, i.e. either on one of the proposals (revision of RTVA and/or No-Billag initiative) and its consequences, on the subject of public service, on Swiss public service organization SRG SSR or on the media market, are recorded. However, if an actor is only mentioned - without an explanation of his/her views - he/she is not coded.

The main actor is the one who is presented as central in the title, subtitle and/or lead. The title, subtitle (if available) and lead are the first criteria for the assignment. If several actors appear in the same text subunit, the order is decisive. If no clear assignment can be made due to title/subtitle/lead, the entire contribution is used. The main actor is then the most extensively presented actor in terms of volume.

The most important secondary actor is determined according to the same criteria as the main actor (if the main actor is not taken into account). The second most important secondary actor is determined according to the same criteria as the 
main actor (if the main actor and the most important secondary actor are not considered).

The journalist can also be coded as an actor if he/she reveals his/her opinion. In the case of commentaries/columns, the author counts as the main actor. In the case of interviews, the interviewee counts as the main actor, but not the journalist."

Values: see Table 1

Intercoder reliability: Intercoder reliability (Krippendorff's Alpha) coefficient of .77 across categories ( 9 coders)

Codebook available at (last accessed on 09.12.2020): $\quad$ https://doi.org/10.5281/zeno-

do. 4312912

\section{INFORMATION ON HILLEBRAND, 2005}

Research interest: Hillebrand (2005) examines how print media outlets report on television (which content, actors, concerns and ways of addressing issues dominate in the coverage and to what extent it includes criticism).

Object of analysis: Purposive sample (four times two weeks around media-relevant events) of articles containing a reference to television in six national daily newspapers, two national weekly newspapers, three television magazines and two media trade journals from Germany.

Time frame of analysis: August 1, 2002 to July 31, 2003

\section{INFORMATION ABOUT VARIABLE \\ Level of analysis: article \\ Operationalization/Coding instructions:}

Hillebrand (2005, Anhang A, own translation):

"Coding is intended to record the actors, sources and witnesses appearing in the article. A main actor and a secondary actor (if applicable) are coded.

Main actor: Who is at the center of the article? Whose actions or statements, interests or preferences are at the core of the article? Who takes up the most space? Whose actions or statements form the reference point to which others then react? Who appears as the 'source' for statements of facts or for evaluations?

The author(s) of an article are not considered as actors! This also applies in cases where TV celebrities such as Kalkofe (TV-Spielfilm) or Beckmann (Zeit) have permanent columns. As actor is recorded the person or collective, who is re- ported on, whose actions are commented on, etc.

Secondary actor: Who else is it about? Same codes to be used as for the main actor."

Values: see Table 2

Intercoder reliability: Intercoder reliability coefficient of .84 across categories (4 coders), not specified for individual category

Codebook available at (last accessed on 09.12.2020): https://www.hans-bredow-institut. de/uploads/media/Publikationen/cms/media/ d666beb1d9130d241ec01915684342eb582b3d42. pdf

\section{REFERENCES}

Hillebrand, C. (2005). Das Fernsehen im Spiegel der Printmedien - Konturen der Berichterstattung. In R. Weiß (Ed.), Zur Kritik der Medienkritik. Wie Zeitungen das Fernsehen beobachten (pp. 33-81). Berlin: Vistas.

Kemner, B., Scherer, H., \& Weinacht, S. (2008). Unter der Tarnkappe. Publizistik, 53(1), 65-84. doi: 10.1007/s11616-008-0006-9

Lichtenstein, D. (2011). Kommerzialisierung des Medienjournalismus? Eine empirische Untersuchung zum „Fall Berliner Zeitung“. M\&K Medien \& Kommunikationswissenschaft, 59(2), 216-234. doi: 10.5771/1615-634x-2011-2-216

Maier, D., \& Dogruel, L. (2016). Akteursbeziehungen in der Zeitungsberichterstattung über die Online-Aktivitäten des öffentlichrechtlichen Rundfunks. Publizistik, 61(2), 145-166. doi: 10.1007/s11616-016-0258-8

Pedrazzi, S. (2020). Codebuch zur Studie «Eigeninteressen in der Berichterstattung über medienpolitische Vorlagen und den Service public in der Schweiz». Zenodo. doi: 10.5281/zenodo.4312912 
Table 1.

Pedrazzi (2020)

Government, administration, parliament or courts as a body or institution and/or individual representatives of the executive, legislative or judiciary system (however, not individual politicians speaking for themselves or their party)

Federal Council

Federal departments, authorities and commissions
Federal Council as a whole or individual members
National Council and Council of States

\section{Cantonal government}

Cantonal administration
Departments (e.g. DETEC), federal offices (e.g. OFCOM) authorities and commissions (e.g. ComCom) and their representatives

Parliament or commissions, including commission presidents or spokespersons when acting in this capacity. Note: Individual parliamentarians must be coded as members of their parties.

Cantonal Government as a whole or individual members acting in this capacity

Cantonal administration and their representatives
Cantonal parliament
Cantonal parliaments

Municipalities

Members of the municipal council, administration, etc.)

Courts

Federal court / cantonal court / district court etc. as well as judges acting in their function

Other bodies or institutions of the government, administration, parliament or justice

\section{Parties and party representatives (incl. party subsections)}

BDP, Bürgerlich-Demokratische Partei 
Pedrazzi (2020)

Junge BDP

CVP, Christlich-demokratische Volkspartei

(inkl. CSP)

Junge CVP

EVP, Evangelische Volkspartei

Junge EVP

FDP, die Liberalen (inkl. LPS/Liberale Partei der Schweiz)

Jungfreisinnige

GLP, Grünliberale Partei

Junge Grünliberale

GPS, Grüne Partei der Schweiz

Junge Grüne

SP, Sozialdemokratische Partei

JUSO

SVP, Schweizerische Volkspartei

Junge SVP

Lega dei Ticinesi 
Pedrazzi (2020)

Mouvement Citoyens Romand

Independents

Other parties

\section{Initiative, referendum and counter committees}

Referendum Committee against the revision of

Committee "Ja zum RTVG"

Committee "Nein zur neuen Billag-Mediensteuer"

Initiative Committee No Billag incl. Olivier Kessler

Committee "NEIN zu No-Billag"

Committee "Nein zum Sendeschluss"

Other initiative, referendum and counter com-

Media, telecommunications and advertising companies and their representatives (incl. owners, editors)

SRG SSR

incl. SRF, RTS, RSI, RTR

NZZ Mediengruppe

incl. Radio FM1, TVO, Tele 1, Radio Pilatus,

Tamedia

Ringier

incl. Radio NRJ 
Pedrazzi (2020)

AZ Medien

incl. Radio Argovia, Radio 24, Radio 32, Tele

M1, Tele Züri, Tele Bärn, etc.

Somedia

Basler Zeitung Medien

3+ Gruppe

ProSieben Sat.1 Gruppe

RTL Gruppe

Teleclub/Swisscom

UPC Cablecom

Sunrise

Orange/Salt

Publisuisse

Goldbach Medien

Other private media companies

\section{Media associations and their representatives}

Verband Schweizer Medien - Médias Suisses -

Stampa Svizzera

VSP - Verband Schweizer Privatradios 
Pedrazzi (2020)

RRR - Radio Régionales Romandes

Unikom - Union nicht-kommerzorientierter

Lokalradios

Telesuisse - Verband der Schweizer Regional-

sender

impressum - Schweizer JournalistInnen

Syndicom

SSM - Schweizer Syndikat Medienschaffender

Swisscable

asut

Schweizer Werbung - Publicité Suisse - Publi-

cità Svizzera

Other media associations

Other associations (economic, cultural, civil society, etc.)

economiesuisse

Schweizerischer Gewerbeverband

Schweizerischer Arbeitgeberverband

avenir suisse

Schweizerischer Gewerkschaftsbund 
Pedrazzi (2020)

Kaufmännischer Verband KV Schweiz

Travail Suisse

Stiftung für Konsumentenschutz

Konsumentenforum

Fédération romande des consommateurs

Associazione consumatrici della Svizzera

Think tanks

Cultural associations

Incl. film and music professionals

Sports associations

Civil society organizations and associations

Other associations

\section{Other economic or socio-cultural actors}

Industry experts

Companies

not operating in the media, telecommunications or advertising industry

Science, research

Celebrities

From sports, culture, show business, etc. 


\section{Pedrazzi (2020)}

Members of the audience (viewers, readers, users) or simple citizens (without representative function)

Author (in case of op-ed articles)

Other actors

\section{Table 2.}

\section{Hillebrand (2005)}

Members of the audience (viewers, readers, users), participants, simple citizens (without representative function)

Media companies, media executives, journalists, celebrities of the media industry

Politicians and all members of the executive and judiciary system

Companies (outside the media industry)

Interest groups (of companies or professions outside the media industry, e.g. from the environmental sector, etc.), churches, etc.

Science, experts, interpreters (writers etc.) - from research and scientific institutions or as self-employed, formally independent from companies, political parties and interest groups

Others

No secondary actor/not decidable 